\title{
A Covid-19 Patient with Complement-Mediated Coagulopathy and Severe Thrombosis
}

\author{
Christopher R. Showers $^{\text {a }}$ Gerard J. Nuovo $^{b, c}$ Amit Lakhanpal $^{d}$ \\ Caroline H. Siegel $^{d}$ Juliet Aizer ${ }^{d}$ Lauren Elreda ${ }^{e}$ Alexandra Halevi ${ }^{f}$ \\ Andrew R. Laig Doruk Erkan ${ }^{\text {h }}$ Cynthia M. Magro ${ }^{i}$ \\ ${ }^{a}$ Department of Medicine, New York-Presbyterian Queens, Weill Cornell Medicine, New York, NY, USA; \\ b The Ohio State University Comprehensive Cancer Center, Powell, OH, USA; ${ }^{\circ}$ Discovery Life Sciences,

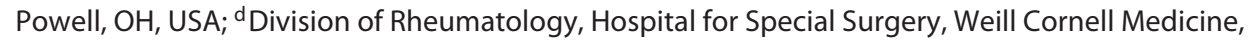

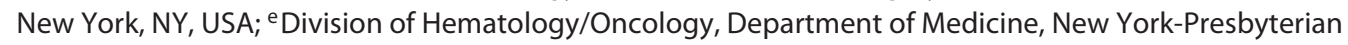 \\ Queens, Weill Cornell Medicine, New York, NY, USA; ' Department of Surgery, New York-Presbyterian Queens, \\ Weill Cornell Medicine, New York, NY, USA; ${ }^{9}$ Division of Hospital Medicine, Department of Medicine,

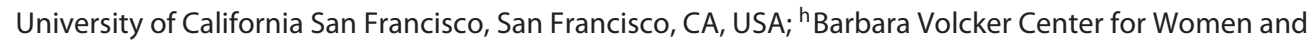 \\ Rheumatic Disease, Hospital for Special Surgery, Weill Cornell Medicine, New York, NY, USA; 'Department of \\ Pathology and Laboratory Medicine, Weill Cornell Medicine, New York, NY, USA
}

\section{Keywords}

COVID-19 · Complement-mediated coagulopathy . Thrombosis

\begin{abstract}
We report a patient with severe Covid-19-associated coagulopathy and type 2 diabetes mellitus who tested positive for antiphospholipid antibodies (aPL). Analysis of skin specimens suggested direct SARS-CoV-2 viral-induced and complementmediated vascular injury and thrombosis, consistent with prior reports. Serial aPL testing demonstrated high levels of anticardiolipin antibodies $(\mathrm{aCL})$ that declined to insignificant levels over a period of 5 weeks. SARS-CoV-2 RNA was detected in nasopharyngeal swab specimens on serial assays performed over the same 5-week period, though it was not detected thereafter. We hypothesize that SARS-CoV-2 viral-induced aPL contributed to severe Covid-19-associated coagulopathy in this patient.

(c) 2020 The Author(s)

Published by S. Karger AG, Basel
\end{abstract}

karger@karger.com

www.karger.com/pat

Karger

GOPEN ACCESS
(C) 2020 The Author(s)

Published by S. Karger AG, Basel

This is an Open Access article licensed under the Creative Commons Attribution-NonCommercial-4.0 International License (CC BY-NC) (http://www.karger.com/Services/OpenAccessLicense), applicable to the online version of the article only. Usage and distribution for commercial purposes requires written permission.

\section{Introduction}

Infection with the SARS-CoV-2 virus causes the clinical disease Covid-19 [1]. In severe cases of Covid-19, patients may develop acute respiratory distress syndrome (ARDS) and multiorgan failure [2, 3]. Systemic inflammation caused by direct viral infection of tissue and severe coagulopathy are proposed mechanisms contributing to multiorgan failure [4]. Indeed, Covid-19-associated coagulopathy may be a key cause of morbidity and mortality in critically ill patients $[5,6]$.

Coagulopathy associated with Covid-19 is characterized by elevated levels of $\mathrm{d}$-dimer and derangements in coagulation times $[7,8]$. Recent reports describe antiphospholipid antibodies (aPL) in Covid-19 patients who suffered multiple thrombotic events [9-12], though few of these reports include individual test details or evidence of persistent aPL. In a recent series of 172 Covid-19 patients, aPL were detected in over half of the cases,

Christopher R. Showers

Department of Medicine, New York-Presbyterian Queens, Weill Cornell Medicine Fifth Floor South Building, 56-45 Main St., Queens

New York, NY 11355 (USA)

crs7004@ nyp.org 

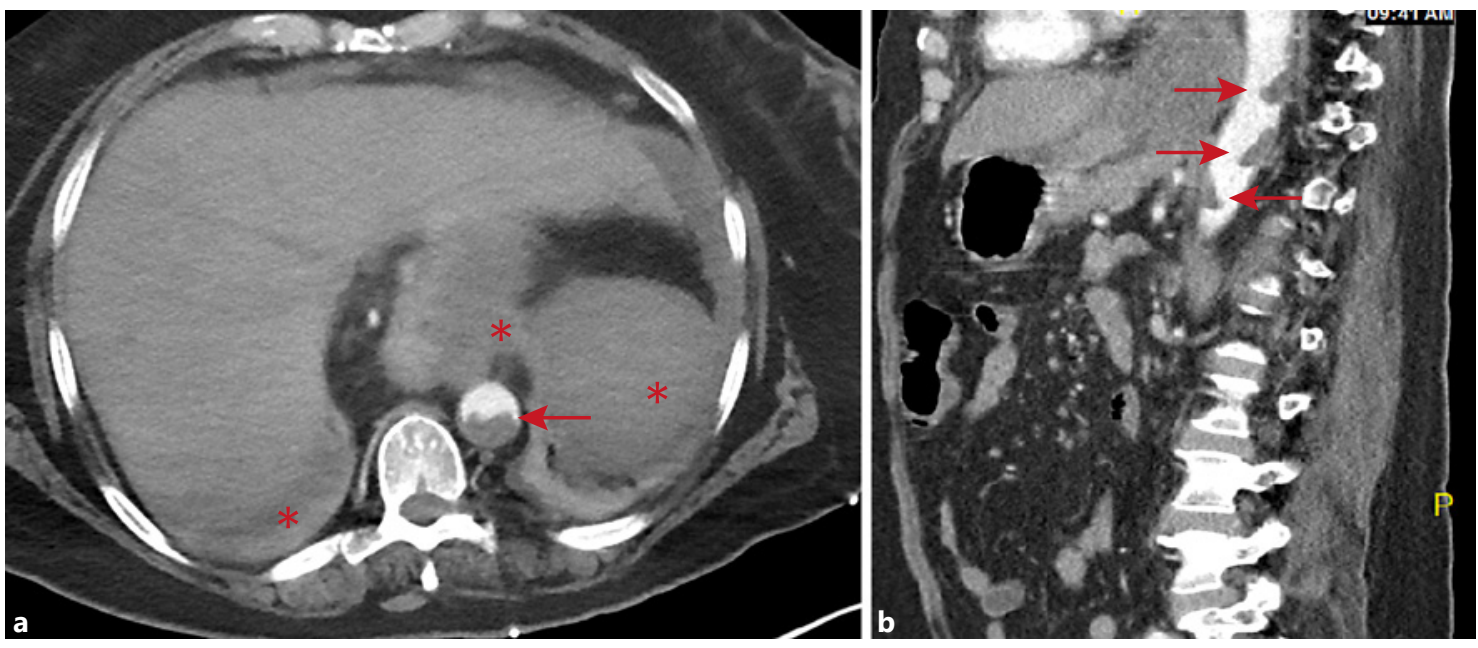

Fig. 1. Abdominal CT angiogram demonstrating large mural thrombi in the suprarenal aorta (arrows). Also visible are complete splenic and partial hepatic and gastric infarcts (asterisks). a Axial projection. b Sagittal projection.

though clinically significant thrombosis occurred in fewer than $10 \%$. Nonetheless, aPL isolated from the serum of these patients was shown to accelerate clot formation when injected into a murine model of thrombosis [13]. Accordingly, the pathophysiological significance of aPL in Covid-19 remains unclear.

We describe a patient with severe Covid-19-associated thrombosis in whom tissue analysis revealed direct viralinduced and complement-mediated mechanisms. The patient tested positive for aPL, though, remarkably, high levels of anticardiolipin antibodies (aCL) gradually declined to clinically insignificant levels over a period of 5 weeks. SARS-CoV-2 RNA was detected in nasopharyngeal swab specimens on serial assays performed over the same 5-week period, though it was not detected thereafter. A multidisciplinary team of physicians at New York Presbyterian/Queens Hospital and New York Presbyterian/Weill Cornell Medical Center managed the care of this patient.

\section{Materials and Methods}

In situ deposition of activated complement components, i.e., C3d, C4d, C5b-9, and MASP-2, a protein formed as a result of mannan-binding lectin (MBL) activation, were conducted on $4-\mu \mathrm{m}$ sections procured from formalin-fixed paraffin-embedded tissue. Immunohistochemical assessment of SARS-CoV-2-associated envelope and membrane proteins was also conducted. All methodologies have been previously described [14].

\section{Case Description}

A 63-year-old woman with a history of type 2 diabetes mellitus (T2DM) complicated by peripheral neuropathy and Charcot foot with chronic osteomyelitis requiring hallux amputation, hypertension, peripheral artery disease, and mild asthma presented following 2 days of progressive shortness of breath and lethargy. She was diagnosed with diabetic ketoacidosis and lactic acidosis and was admitted to an intensive care unit. She tested positive for SARSCoV-2 infection by reverse transcriptase-polymerase chain reaction (RT-PCR) performed on a nasopharyngeal swab specimen. Initial laboratory analysis revealed a d-dimer level of $6,197 \mathrm{ng} / \mathrm{mL}$, a platelet count of $533 \mathrm{~K} / \mu \mathrm{L}$, an activated partial thromboplastin time (aPTT) of $33.4 \mathrm{~s}$, a fibrinogen level of $1,196 \mathrm{mg} / \mathrm{dL}$, a venous lactate level of $10.51 \mathrm{mmol} / \mathrm{L}$, and a hemoglobin Alc amount of 10.2\% (Table 1).

Following resolution of acidosis, her mental status normalized and she reported diffuse abdominal pain. CT angiography revealed multiple large mural thrombi in the suprarenal abdominal aorta, thrombi in the splenic artery and vein, and infarcts of the spleen, stomach, and liver (Fig. 1). She developed progressive painless lower extremity mottling and discoloration; vascular studies showed occlusions of the right posterior tibial, left anterior tibial, left posterior tibial, and left peroneal arteries. In light of irreversible ischemic damage, she underwent bilateral below-the-knee amputations (BKA) on hospital day 12. Subsequent noncontrast CT chest imaging revealed multiple peripheral wedge-shaped lung consolidations. A transthoracic echocardiogram (TTE) performed on the tenth day of hospitalization revealed no evidence of endocarditis or intracardiac thrombi and blood cultures were negative.

Upon further questioning, the patient reported 3 uncomplicated pregnancies. Three years prior to admission, she experienced a nonhealing ulcer following minor trauma that led to a right hallux amputation. She denied a history of aPL positivity or thrombosis.

Laboratory analysis performed on the tenth day of hospitalization revealed significantly elevated aCL IgG and IgM levels. Anti- $\beta_{2}$-glycoprotein-I $\left(a \beta_{2} \mathrm{GPI}\right)$ and antinuclear antibodies 
Table 1. Laboratory analysis

\begin{tabular}{|c|c|c|}
\hline Parameter & Value & Reference range \\
\hline \multicolumn{3}{|l|}{ Laboratory profile at admission } \\
\hline White-cell count, $\mathrm{n} \times 1,000 / \mathrm{uL}$ & 18.41 & $4.80-10.90$ \\
\hline \multicolumn{3}{|l|}{ Differental count } \\
\hline Neutrophils, \% & 78.9 & $45-75$ \\
\hline Lymphocytes, \% & 14.1 & $20-50$ \\
\hline Hemoglobin, g/dL & 8.4 & $13.3-17.7$ \\
\hline Platelet count, $\mathrm{n} \times 1,000 / \mathrm{uL}$ & 484 & $150-400$ \\
\hline Alanine aminotransferase, U/L & 1,459 & $5-41$ \\
\hline Aspartate aminotransferase, $\mathrm{U} / \mathrm{L}$ & 562 & $5-40$ \\
\hline Creatinine, $\mathrm{mg} / \mathrm{dL}$ & 2.07 & $0.70-1.30$ \\
\hline EGFR, $\mathrm{mL} / \mathrm{min} / 1.73 \mathrm{~m}^{2}$ & 24 & $>60$ \\
\hline Glucose, mg/dL & 629 & 74-106 \\
\hline$\beta$-hydroxybutiric acid, mmol/L & 1.2 & $0.02-0.27$ \\
\hline Hemoglobin Alc, \% & 10.2 & $4.0-6.4$ \\
\hline Lactate, venous, mmol/L & 10.51 & $0.5-1.6$ \\
\hline Prothrombin time, $s$ & 16.7 & $10-13$ \\
\hline Activated partial thromboplastin time, s & 33.4 & $26.6-36.5$ \\
\hline Fibrinogen, mg/dL & 1,196 & $250-490$ \\
\hline D-dimer, $\mathrm{ng} / \mathrm{mL}$ & 6,197 & $0-229$ \\
\hline Serum ferritin, ng/mL & 504 & $13-150$ \\
\hline C-reactive protein, mg/dL & 38.98 & $0.03-0.49$ \\
\hline Lactate dehydrogenase, $\mathrm{U} / \mathrm{L}$ & 1,250 & $135-225$ \\
\hline $\mathrm{pH}$ (venous) & 6.68 & $7.35-7.45$ \\
\hline $\mathrm{pCO}_{2}$ (venous), $\mathrm{mm} \mathrm{Hg}$ & 35 & $41-51$ \\
\hline $\mathrm{pO}_{2}$ (venous), $\mathrm{mm} \mathrm{Hg}$ & 37 & $25-40$ \\
\hline SARS-CoV-2 RT-PCR & Detected & Not detected \\
\hline \multicolumn{3}{|l|}{ Timeline of additional studies } \\
\hline \multicolumn{3}{|l|}{ Hospital day $10^{\mathrm{a}}$} \\
\hline Anticardiolipin antibody IgG (GPL) & 119 & $<14$ \\
\hline Anticardiolipin antibody IgM (MPL) & 59 & $<12$ \\
\hline Anticardiolipin antibody IgA (APL) & $<11$ & $<11$ \\
\hline Anti- $\beta_{2}$-glycoprotein-I IgG, IgM, IgA (SGU, SMU, SAU) & $<9$ & $<9$ \\
\hline \multicolumn{3}{|l|}{ Hospital day $13^{\mathrm{a}}$} \\
\hline C3 complement, mg/dL & 171 & $90-180$ \\
\hline $\mathrm{C} 4$ complement, mg/dL & 40 & $10-40$ \\
\hline \multicolumn{3}{|l|}{ Hospital day $14^{\mathrm{a}}$} \\
\hline Activated partial thromboplastin time, s & 49.8 & $26.6-36.5$ \\
\hline Lupus anticoagulant PTT screen, $s$ & 49 & $<40$ \\
\hline Thrombin clotting time, $\mathrm{s}$ & 19 & $13-19$ \\
\hline Dilute Russell viper venom time, $s$ & 28 & $<45$ \\
\hline Lupus anticoagulant hexagonal phase confirmation & Weak positive & Negative \\
\hline Protease- 3 antibody, $\mathrm{AU} / \mathrm{mL}$ & 2.3 & $<1.0$ \\
\hline Myeloperoxidase antibody, $\mathrm{AU} / \mathrm{mL}$ & 0 & $<1.0$ \\
\hline \multicolumn{3}{|l|}{ Hospital day $17^{\mathrm{a}}$} \\
\hline C3 complement, mg/dL & 154 & $90-180$ \\
\hline $\mathrm{C} 4$ complement, $\mathrm{mg} / \mathrm{dL}$ & 41.7 & $10-40$ \\
\hline Complement $\mathrm{CH} 50$, CAE units & 120 & $60-144$ \\
\hline \multicolumn{3}{|l|}{ Hospital day 18} \\
\hline SARS-CoV-2 RT-PCR & Detected & Not detected \\
\hline Activated partial thromboplastin time, $s$ & 39.8 & $26.6-36.5$ \\
\hline Lupus anticoagulant PTT screen, s & 40 & $32-48$ \\
\hline Dilute Russell viper venom time, $s$ & 29 & $22-44$ \\
\hline Anticardiolipin antibody IgG (GPL) & 80 & $<14$ \\
\hline Anticardiolipin antibody IgM (MPL) & 19 & $<12$ \\
\hline Anticardiolipin antibody IgA (APL) & 6.6 & $<11$ \\
\hline Anti- $\beta_{2}$-glycoprotein-I IgG, IgM, IgA (SGU, SMU, SAU) & $<9$ & $<9$ \\
\hline \multicolumn{3}{|l|}{ Hospital day $19^{\mathrm{a}}$} \\
\hline Protease-3 antibody, AU/mL & 132 & $<1.0$ \\
\hline Myeloperoxidase antibody, AU/mL & 0 & $<1.0$ \\
\hline \multicolumn{3}{|l|}{ Hospital day $20^{\mathrm{a}}$} \\
\hline C3 complement, mg/dL & 155 & $90-180$ \\
\hline C4 complement, mg/dL & 46.9 & $10-40$ \\
\hline $\mathrm{C} 8$ complement, mg/dL & 14.8 & $10.7-24.9$ \\
\hline $\mathrm{C} 9$ complement, $\mathrm{mg} / \mathrm{dL}$ & 41 & $6.0-29.0$ \\
\hline
\end{tabular}


Table 1 (continued)

\begin{tabular}{|c|c|c|}
\hline Parameter & Value & Reference range \\
\hline \multicolumn{3}{|l|}{ Hospital day $33^{\mathrm{b}, \mathrm{c}}$} \\
\hline SARS-CoV-2 RT-PCR & Detected & Not detected \\
\hline \multicolumn{3}{|l|}{ Hospital day $34^{c}$} \\
\hline COVID-19 antibody assay & Positive & Negative \\
\hline \multicolumn{3}{|l|}{ Hospital day $38^{\mathrm{c}}$} \\
\hline Anticardiolipin antibody IgG (GPL) & 40 & $<14$ \\
\hline Anticardiolipin antibody IgM (MPL) & 9.6 & $<12$ \\
\hline Anticardiolipin antibody IgA (APL) & 4.1 & $<11$ \\
\hline Anti- $\beta_{2}$-glycoprotein-I IgG, IgM, IgA (SGU, SMU, SAU) & $<9$ & $<9$ \\
\hline Protease- 3 antibody, $\mathrm{AU} / \mathrm{mL}$ & 73 & $<1.0$ \\
\hline Myeloperoxidase antibody, AU/mL & 1 & $<1.0$ \\
\hline \multicolumn{3}{|l|}{ Hospital day $40^{c}$} \\
\hline SARS-CoV-2 RT-PCR & Detected & Not detected \\
\hline \multicolumn{3}{|l|}{ Hospital day $46^{c}$} \\
\hline Dilute Russell viper venom time screen, ratio & 1.2 & $<1.2$ \\
\hline Lupus anticoagulant silica clotting time screen, ratio & 1.0 & $<1.2$ \\
\hline Anticardiolipin antibody IgG (GPL) & 20.9 & $<14$ \\
\hline Anticardiolipin antibody IgM (MPL) & 7.5 & $<12$ \\
\hline Anticardiolipin antibody IgA (APL) & 9.0 & $<11$ \\
\hline Anti- $\beta_{2}$-glycoprotein-I IgG, IgM, IgA (SGU, SMU, SAU) & $<9$ & $<9$ \\
\hline \multicolumn{3}{|l|}{ Hospital day $47^{c}$} \\
\hline SARS-CoV-2 RT-PCR & Indeterminate & Not detected \\
\hline \multicolumn{3}{|l|}{ Hospital day $49^{c}$} \\
\hline SARS-CoV-2 RT-PCR & Not detected & Not detected \\
\hline \multicolumn{3}{|l|}{ Hospital day $50^{c}$} \\
\hline SARS-CoV-2 RT-PCR & Not detected & Not detected \\
\hline
\end{tabular}

${ }^{a}$ Patient on continuous heparin infusion. ${ }^{b}$ Patient on continuous argatroban Infusion. ${ }^{c}$ Patient on oral warfarin.

(ANA) were not detected. A lupus anticoagulant (LA) sensitive PTT screen (LA-PTT) performed on the fourteenth day, while the patient was receiving a continuous heparin infusion, was positive; an LA hexagonal phase confirmation test was weakly positive. A dilute Russell viper venom time (dRVVT) assay was not prolonged. Antibodies directed against proteinase-3 (PR3; c-ANCA) were detected. Continuous heparin infusion was temporarily interrupted during inter-institutional transfer on the eighteenth day of hospitalization; an LA-PTT at that time was negative, and a dRVVT was not prolonged. Serum analyses on the eighteenth, thirty-eighth, and forty-sixth days of hospitalization showed a progressive decline in aCL levels; IgG and IgM levels fell to or below the threshold of clinical significance. Serum levels of complement C3 and C4 proteins remained within or slightly above a normal range.

Serial RT-PCR assays performed on nasopharyngeal swab specimens detected SARS-CoV-2 RNA on the eighteenth, thirtysecond, and fortieth days of hospitalization; an assay was indeterminate on the forty-seventh day and assays on the forty-ninth and fiftieth days were negative. Serum antibodies to SARS-CoV-2 were detected on the thirty-fourth day of hospitalization. A timeline of relevant laboratory analyses is provided in Table 1 . Genetic testing revealed factor V Leiden variant (R506Q) heterozygosity. There was no evidence of occult malignancy based on tumor markers or extensive imaging.

Platelet counts rose progressively, reaching a maximum of $1,014 \mathrm{~K} / \mathrm{uL}$ prior to bilateral BKA, and remained moderately elevated thereafter. D-dimer and fibrinogen levels trended downward to normal ranges and ferritin remained elevated throughout hos- pitalization. Serum creatinine decreased from a peak of $2.07 \mathrm{mg} /$ $\mathrm{dL}$ at admission and remained within her baseline range (1.0-1.5 $\mathrm{mg} / \mathrm{dL}$ ) thereafter.

Heparin, aspirin, hydroxychloroquine, and atorvastatin were initiated shortly after admission. Heparin dosing was guided by aPTT, though measurements of anti-factor Xa were also used. Following bilateral BKA, the patient was treated with a pulse of intravenous methylprednisolone $500 \mathrm{mg}$ daily for 3 days followed by a steroid taper. Surveillance imaging 1 week after surgery demonstrated a new right femoral artery occlusion and a possible new right subsegmental pulmonary embolism; intravenous heparin was subsequently stopped and intravenous argatroban was initiated. Intravenous immunoglobulin (IVIg) therapy was given to further mitigate the risk of antibody-mediated thromboembolic events. Additional imaging 3 weeks after surgery revealed a reduced clot burden and no evidence of new clot formation. Warfarin was initiated during the fourth week of hospitalization. The patient required minimal or no oxygen therapy.

\section{Pathologic Description}

Tissue analysis of skin specimens obtained from the amputated lower extremities showed extensive occlusion of small and medium sized arterial and venous vessels and capillaries by fibrin thrombi, associated with ischemic epidermal denudement and necrosis (Fig. 2a). Significant deposition of C3d, C4d, C5b-9, and MASP-2 was observed within the microvasculature and in small and medium sized arteries and veins throughout the dermis and subcutaneous fat (Fig. 2b). Staining for CD61 was strongly positive in many thrombi, indicating the presence of platelets (Fig. 2c). A 


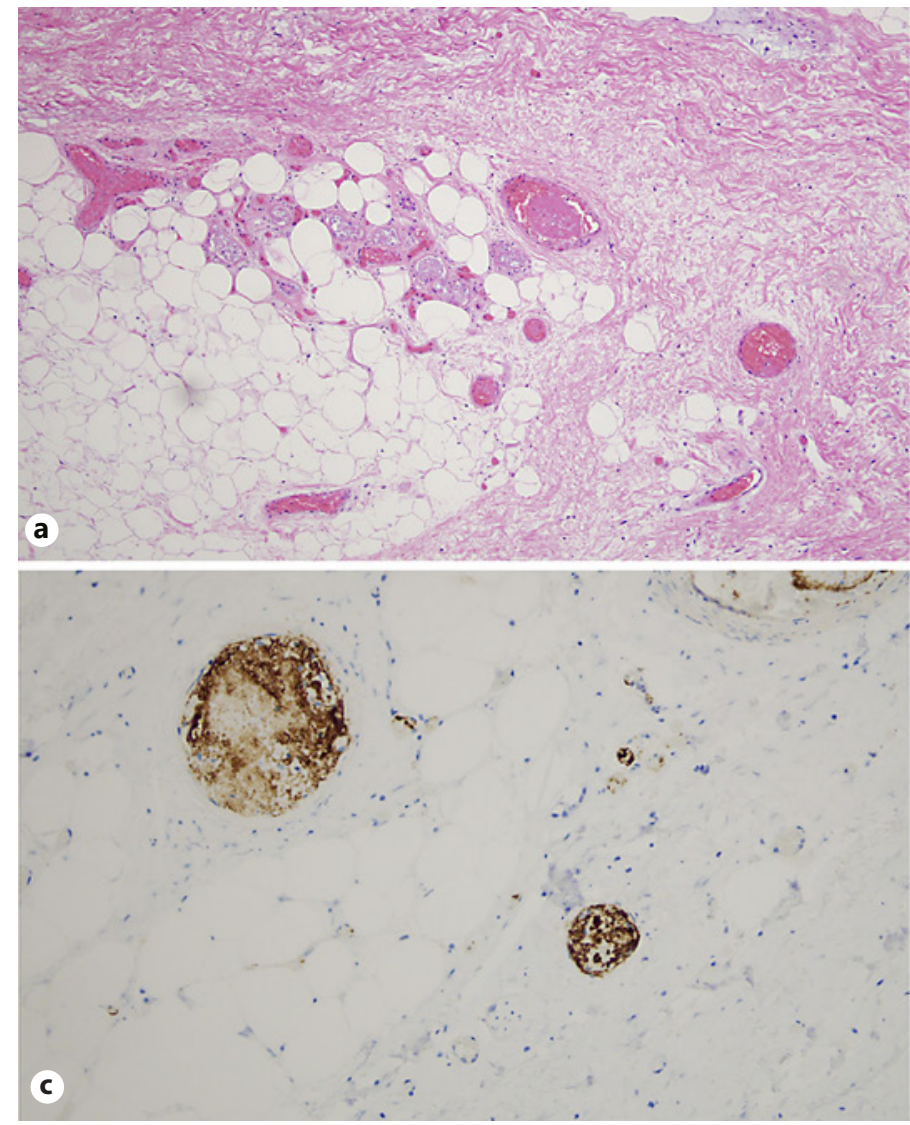

Fig. 2. Tissue analysis of skin specimens from lower extremity amputation. Extensive occlusion of small and medium sized arterial and venous vessels and capillaries by fibrin thrombi was noted, and it was associated with ischemic epidermal denudement and necrosis. a Hematoxylin and eosin. $\times 200$. Significant deposits of C5b-9 were observed within vessel walls, including the endothelium and

number of deep vessels demonstrated endothelial cell staining of SARS-CoV-2 viral envelope and membrane proteins; roughly $20 \%$ of the vessels stained positive (Fig. 2d). There was no evidence of SARS-CoV-2 viral RNA.

\section{Discussion}

We describe a 63-year-old woman with a history of diabetic vasculopathy and peripheral artery disease who presented with extensive Covid-19-associated macrovascular and microvascular thromboses. Analysis of skin specimens revealed diffuse pauci-inflammatory microvascular injury and thrombosis characterized by extensive complement activation and the presence of viral proteins within vascular endothelial cells. The patient tested

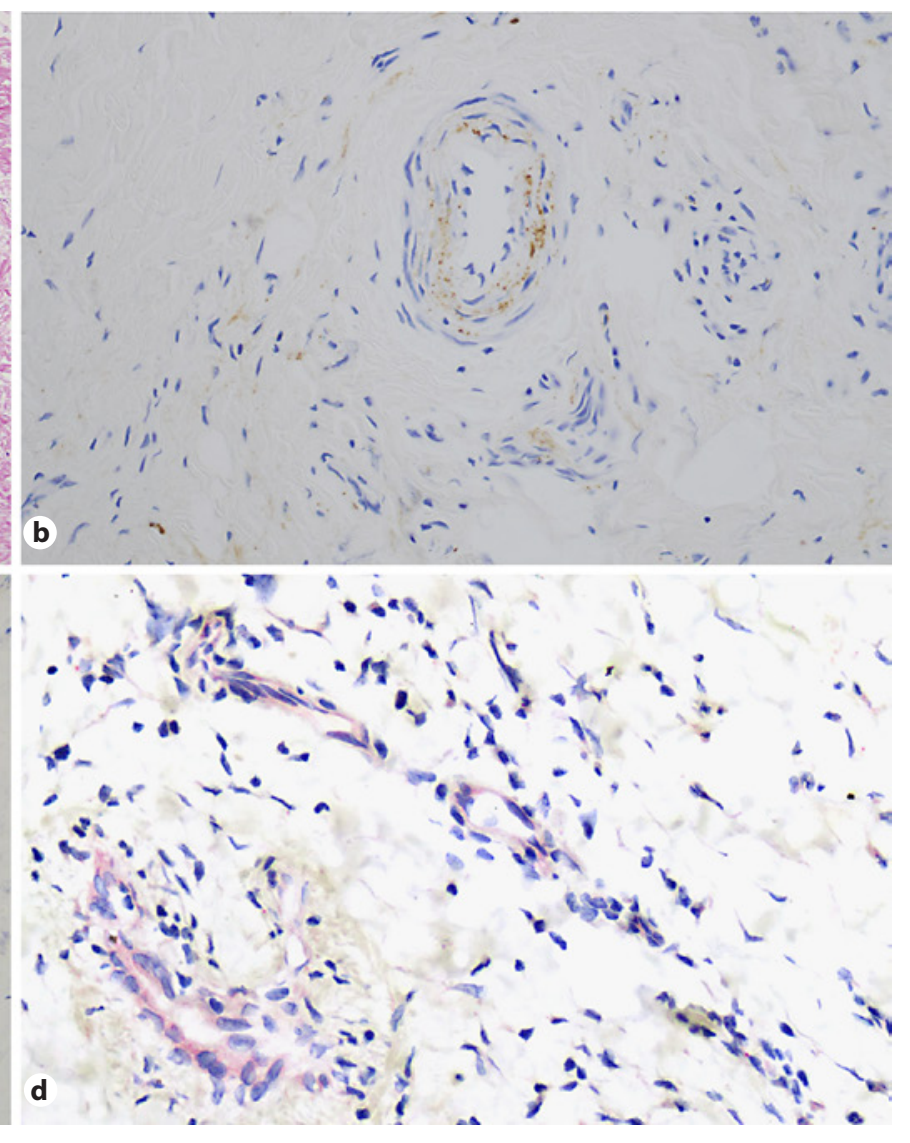

intima of arteries. $\mathbf{b}$ Diaminobenzidene. $\times 400$. CD61 was strongly positive in many thrombi, indicative of the platelet-rich nature of the thrombi. c Diaminobenzidene. $\times 400$. Deep-seated vessels showed endothelial cell staining of viral envelope and membrane proteins; roughly $20 \%$ of the vessels were positive. $\mathbf{d}$ Red chromagen. $\times 400$. positive for aPL and received high-dose steroids and IVIg. Remarkably, high aCL levels gradually declined to clinically insignificant levels over a period of 5 weeks, approximately the same period over which SARS-CoV-2 RNA became undetectable in nasopharyngeal swab specimens.

The presence of SARS-CoV-2 viral proteins within the vascular endothelium confirms direct vascular involvement, notably without active viral replication. Prior research demonstrates that MBL binds SARS-CoV-1 spike glycoproteins [15]; more recent research demonstrates that the SARS-CoV-2 nucleocapsid (N) protein binds MBL and activates MASP-2, leading to enhanced activation of complement in vitro and enhanced deposition of activated complement in a murine model of pneumonia [16]. The intense staining of C4d and MASP-2 in the presence of SARS-CoV-2 glycoproteins in this patient 
similarly suggests an interaction between MBL and SARS$\mathrm{CoV}-2$, triggering activation of the lectin complement pathway (LP). The presence of C3d in vascular endothelial cells suggests amplification of the alternative complement pathway (AP). Intense staining of the C5b-9 membrane attack complex in endothelial cells demonstrates involvement of the terminal complement complex, known to induce endothelial cell and platelet activation, cytolysis, apoptosis, and ultimately clot formation [17, 18]. Activation of the LP may also promote thrombosis directly through MASP-2 cleavage of prothrombin and through the prothrombotic actions of $\mathrm{C} 5 \mathrm{a}$ anaphylatoxin $[19,20]$. Indeed, a preclinical model of SARS developed using the SARS-CoV-1 virus emphasized the potential role of complement, demonstrating significantly less disease in mice lacking complement C3 proteins when compared to wild-type mice [21]. More recently, elevated serum levels of C5a and soluble C5b-9 were observed in severely ill Covid-19 patients [22], and inhibition of C5a signaling in a murine model of Covid-19 limited myeloid cell infiltration in lung tissue, resulting in abatement of acute lung injury [23].

The pattern of tissue injury we observed recapitulates a prior report demonstrating SARS-CoV-2 viral proteins, intense complement activation, diffuse thrombosis, and pauci-inflammatory microvascular injury in Covid-19 lung and skin autopsy specimens [14]. Notably, in this patient, activated complement was observed far more extensively than was viral protein uptake in microvascular cells. Larger vessels demonstrated deposition of activated complement and thrombosis, though there was a lack of evidence of viral protein uptake. Additionally, this patient did not progress to ARDS or renal failure and did not demonstrate persistent laboratory findings suggestive of severe immune hyperactivation (cytokine storm), features typically associated with Covid-19-associated coagulopathy $[4,6,18]$. Taken together, these findings suggest the contribution of additional complement triggering mechanisms not directly related to viral protein uptake.

This patient tested positive for aPL; however, the interpretation of aPL studies deserves special attention as not every positive aPL test is clinically meaningful [24, 25]. Serial testing in this patient demonstrated moderateto-high levels of aCL IgG and IgM on multiple occasions that progressively declined 6-fold over five weeks. Historical studies have established an increased probability of thrombosis related to both the IgG and the IgM fractions of aCL $[26,27]$. Importantly, aCL assays are nonspecific in that cardiolipin contains multiple phospholipid

Covid-19 with Complement-Mediated

Coagulopathy and Severe Thrombosis and protein cofactor epitopes; therefore, a positive aCL assay may reflect a range of different epitope-specific autoantibodies [28]. Anticardiolipin assay positivity may result from a $\beta_{2}$ GPI, known to be potently thrombogenic [29], though aCL assays can detect other pathogenic aPL in the absence of $\mathrm{a} \beta_{2}$ GPI $[28,30]$.

An initial LA assay in this patient was weakly positive; however, LA may be transiently positive in critically ill patients independently of aPL, particularly when patients are receiving anticoagulation therapy or when C-reactive protein levels are elevated [31,32]. Multiple repeat LA assays performed while this patient was not receiving heparin were negative.

Antiphospholipid syndrome (APS) is a systemic autoimmune disease characterized by arterial and venous thrombosis in patients with aPL that persist after 12 weeks [25]. Catastrophic antiphospholipid syndrome is an accelerated form of APS characterized by severe thrombosis acutely affecting multiple organs [33]. Infections can induce aPL positivity [34] and acute infection can trigger thrombosis in aPL-positive patients [29]. In this context, aPL-positive Covid-19 patients have been reported, though most of these reports provide a limited interpretation of aPL tests and therefore offer a limited interpretation of their role in disease $[12,35]$. Following serial testing, we hypothesize that transient but high levels of aPL contributed to severe acute coagulopathy in this patient. Furthermore, assuming that she was never aPL positive prior to Covid-19 disease, we hypothesize that SARSCoV-2 infection triggered the transiently high levels of aPL. Remarkably, serial RT-PCR assays on nasopharyngeal swab specimens detected SARS-CoV-2 RNA repeatedly over a 5-week period, though they failed to detect viral RNA at approximately the same time that aPL levels fell below a clinically significant threshold. These observations suggest that resolution of nasopharyngeal infection and clearance of aPL were related and lend support to our hypothesis that SARS-CoV-2 infection precipitated the generation of aPL in this patient.

Murine models have demonstrated that complement activation is required for aPL-induced thrombosis and that deficiency or inhibition of complement results in reduced thrombosis in the presence of aPL following vascular injury [36]. The histological pattern of injury in this case does resemble APS [37], and the greater extent of complement activation and thrombosis, relative to viral protein uptake, may suggest a pathologic contribution from aPL. The recent observation that, when injected into a murine model of thrombosis, the purified IgG fraction of aPL isolated from Covid-19 patients enhanced throm- 
bus extension and accretion provides further support for a pathogenic role of aPL in Covid-19 [13]. Nonetheless, a recent series of critically ill Covid-19 patients found no association between low to moderate aPL titers and thrombosis [38], challenging claims that aPL contribute to Covid-19-associated coagulopathy. Still, the authors caution that in the setting of widespread endothelial cell activation, even low levels of aPL may accumulate at sufficient density to potentiate thrombosis.

The generation of aPL in this patient may have resulted from exposure of cellular and membrane neoantigens following viral-induced and complement-mediated cell injury and apoptosis. This phenomenon of epitope spreading in the setting of a proapoptotic microenvironment is known to occur, such as during parvovirus B19 and cytomegalovirus infections, and may contribute to disease $[39,40]$.

Though the presence of PR3 is highly specific for granulomatosis with polyangiitis, this patient showed no evidence of alveolar hemorrhage, glomerulonephritis, or other skin, ocular, nasal, or neurologic manifestations of granulomatosis with polyangiitis [41]. Wedge-shaped consolidations noted on CT chest imaging suggested pulmonary infarction likely resulting from pulmonary embolism. Furthermore, tissue analysis of skin specimens did not reveal evidence of vasculitis. Interestingly, leukocyte protease-3 is a known component of neutrophil extracellular traps (NET), extracellular webs of chromatin, microbicidal proteins, and oxidant enzymes that are released by neutrophils to contain infections [42]. Multiple markers of NET are elevated in patients with Covid-19 [43], and complex mutually amplifying mechanisms exist between NET and the complement and coagulation systems $[44,45]$. Therefore, the high levels of PR3 in this patient could represent neoantigen antibodies against extracellular leukocyte protease 3 extruded from activated neutrophils as a component of NET. Furthermore, if present and reciprocally activating the complement and coagulations systems, NET may present an additional driver of the extensive complement deposition and thrombosis observed in this patient. Notably, myeloperoxidase is also a component of NET [42, 43], though antibodies to myeloperoxidase (p-ANCA) were not detected in this patient. PR3 levels trended downward in tandem with aPL, though PR3 levels were not measured following resolution of nasopharyngeal infection, and thus it remains unknown if PR3 continued to decline to insignificant levels. Certainly, further investigation is necessary to clarify the role of NET and PR3 in Covid-19.
The impact of this patient's T2DM on disease severity cannot be ignored. Reports of diabetic ketoacidosis as a consequence of Covid-19 are emerging and suggest that direct viral infection of the pancreas may worsen $\beta$-cell injury and impede insulin secretion [46]. Vascular deposition of C5b-9 is a known feature of diabetic vasculopathy, proposed to result from glycosylation and inactivation of CD59, a complement regulatory protein that restricts assembly and deposition of membrane attack complex $[47,48]$. Inactivated CD59 permits deposition of C5b-9 in endothelial cell membranes, releasing vascular growth factors that drive the neovascularization underlying many complications of T2DM [49] and allowing complement split products to potentiate thrombosis [20, 49]. Direct viral uptake by vascular cells in the context of this patient's T2DM likely produced an imbalance in the complement system leading to activation.

In summary, we present a patient with severe Covid19-associated coagulopathy and T2DM who tested positive for aPL. Analysis of skin specimens suggested direct SARS-CoV-2 viral-induced and complement-mediated vascular injury and thrombosis, consistent with prior reports. Notably, deposition of activated complement was observed far more extensively in the vasculature than was uptake of viral particles. Serial aPL testing demonstrated high levels of aCL that declined to insignificant levels over a period of 5 weeks, approximately the same period over which SARS-CoV-2 RNA became undetectable in nasopharyngeal swab specimens. We propose that SARSCoV-2 infection induced transient aPL that contributed to severe Covid-19 coagulopathy in this patient. It is our hope that further investigation will clarify the role of aPL in Covid-19-associated coagulopathy and that rigorous analysis of Covid-19 patients may provide further insight into the etiopathogenesis of APS.

\section{Acknowledgement}

The authors would like to acknowledge individuals who contributed significantly to the care of this patient, including Dr. Miri Kim, Dr. Roxana Lazarescu, Dr. Irina Abramova, Dr. Varuna Sundaram, Dr. Gregory Mints, Dr. Justin Lebenthal, Dr. William Levine, Dr. Jeffrey C. Laurence, Dr. Bobak Parang, Dr. Benedict Osorio, and Dr. Ezra Gabbay. Dr. Andrew R. Lai cared for this patient and contributed to this report while serving as a visiting physician at New York-Presbyterian Queens, Weill Cornell Medicine. Specialized tissue analysis was performed at the Weill Cornell Medical Center and at the Ohio State University Comprehensive Cancer Center. Finally, the authors wish to acknowledge the courage and resilience this patient demonstrated while confronting the serious illness reported.
Showers/Nuovo/Lakhanpal/Siegel/Aizer/ Elreda/Halevi/Lai/Erkan/Magro 


\section{Statement of Ethics}

Informed consent was obtained from the patient for publication of this case report and any accompanying images. The Weill Cornell Medicine Institutional Review Board determined that the activities of this case report did not constitute human subjects research, and therefore neither approval nor a notice of exemption was required.

\section{Conflict of Interest Statement}

All of the authors have no conflict of interests to declare.

\section{Funding Sources}

All of the authors have no funding sources to declare relevant to this report.

\section{Author Contributions}

C.R.S. drafted the initial version of this paper and managed subsequent revisions; A.L., C.H.S., J.A., L.E., A.H., A.R.L., and D.E. contributed equally to revisions of this work. C.M.M. and G.J.N. performed all tissue analyses and contributed equally to revisions of this work.

\section{References}

1 Chen N, Zhou M, Dong X, Qu J, Gong F, Han $\mathrm{Y}$, et al. Epidemiological and clinical characteristics of 99 cases of 2019 novel coronavirus pneumonia in Wuhan, China: a descriptive study. Lancet. 2020 Feb;395(10223):507-13.

2 Huang C, Wang Y, Li X, Ren L, Zhao J, Hu Y, et al. Clinical features of patients infected with 2019 novel coronavirus in Wuhan, China. Lancet. 2020 Feb;395(10223):497-506.

3 Wang D, Hu B, Hu C, Zhu F, Liu X, Zhang J, et al. Clinical Characteristics of 138 Hospitalized Patients With 2019 Novel CoronavirusInfected Pneumonia in Wuhan, China. JAMA. 2020 Mar;323(11):1061-9.

4 Jose RJ, Manuel A. COVID-19 cytokine storm: the interplay between inflammation and coagulation. Lancet Respir Med. 2020 Jun;8(6):e46-7.

5 Zhou F, Yu T, Du R, Fan G, Liu Y, Liu Z, et al. Clinical course and risk factors for mortality of adult inpatients with COVID-19 in Wuhan, China: a retrospective cohort study. Lancet. 2020 Mar;395(10229):1054-62.

6 Helms J, Tacquard C, Severac F, Leonard-Lorant I, Ohana M, Delabranche X, et al.; CRICS TRIGGERSEP Group (Clinical Research in Intensive Care and Sepsis Trial Group for Global Evaluation and Research in Sepsis). High risk of thrombosis in patients with severe SARS-CoV-2 infection: a multicenter prospective cohort study. Intensive Care Med. 2020 Jun;46(6):1089-98.

7 Tang N, Li D, Wang X, Sun Z. Abnormal coagulation parameters are associated with poor prognosis in patients with novel coronavirus pneumonia. J Thromb Haemost. 2020 Apr; 18(4):844-7.

8 Xiong M, Liang X, Wei YD. Changes in blood coagulation in patients with severe coronavirus disease 2019 (COVID-19): a meta-analysis. Br J Haematol. 2020 Jun;189(6):1050-2.

9 Zhang Y, Xiao M, Zhang S, Xia P, Cao W, Jiang W, et al. Coagulopathy and Antiphospholipid Antibodies in Patients with Covid-19. N Engl J Med. 2020 Apr;382(17):e38.
10 Bowles L, Platton S, Yartey N, Dave M, Lee K, Hart DP, et al. Lupus anticoagulant and abnormal coagulation tests in patients with $\mathrm{Co}$ vid-19. N Engl J Med. 2020 Jul;383(3):288-90.

11 Harzallah I, Debliquis A, Drénou B. Lupus anticoagulant is frequent in patients with $\mathrm{Co}$ vid-19. J Thromb Haemost. 2020. doi: 10.1111/jth.14867.

12 Hossri S, Shadi M, Hamarsha Z, Schneider R, El-Sayegh D. Clinically significant anticardiolipin antibodies associated with COVID-19. J Crit Care. 2020 Oct:59:32-4

13 Zuo Y, Estes SK, Gandhi AA, Yalavarthi S, Ali RA, Shi H, et al. Prothrombotic antiphospholipid antibodies in COVID-19. medRxiv. 2020. doi: https://doi.org/10.1101/2020.06.15 .20131607.

14 Magro C, Mulvey JJ, Berlin D, Nuovo G, Salvatore S, Harp J, et al. Complement associated microvascular injury and thrombosis in the pathogenesis of severe COVID-19 infection: a report of five cases. Transl Res. 2020. doi: 10.1016/j.trsl.2020.04.007

15 Zhou Y, Lu K, Pfefferle S, Bertram S, Glowacka I, Drosten C, et al. A single asparaginelinked glycosylation site of the severe acute respiratory syndrome coronavirus spike glycoprotein facilitates inhibition by mannosebinding lectin through multiple mechanisms. J Virol. 2010 Sep;84(17):8753-64.

16 Gao T, Hu M, Zhang X, Li H, Zhu L, Liu H, et al. (2020). Highly pathogenic coronavirus $N$ protein aggravates lung injury by MASP2-mediated complement over-activation. medRxiv : the Preprint Server for Health Sciences, 2020.03.29.20041962. http://doi.org/ https://doi.org/10.1101/2020.03.29.20041962.

17 Nauta AJ, Daha MR, Tijsma O, van de Water B, Tedesco F, Roos A. The membrane attack complex of complement induces caspase activation and apoptosis. Eur J Immunol. 2002 Mar;32(3):783-92.

18 Fletcher-Sandersjöö A, Bellander BM. Is COVID-19 associated thrombosis caused by overactivation of the complement cascade? A literature review. Thromb Res. 2020 Jun;194: 36-41.
19 Wojta J, Kaun C, Zorn G, Ghannadan M, Hauswirth AW, Sperr WR, et al. C5a stimulates production of plasminogen activator inhibitor-1 in human mast cells and basophils. Blood. 2002 Jul;100(2):517-23.

20 Krarup A, Wallis R, Presanis JS, Gál P, Sim RB. Simultaneous activation of complement and coagulation by MBL-associated serine protease 2. PLoS One. 2007 Jul;2(7):e623.

21 Gralinski LE, Sheahan TP, Morrison TE, Menachery VD, Jensen K, Leist SR, et al. Complement Activation Contributes to Severe Acute Respiratory Syndrome Coronavirus Pathogenesis. MBio. 2018 Oct;9(5):e01753-18.

22 Cugno M, Meroni PL, Gualtierotti R, Griffini S, Grovetti E, Torri A, et al. Complement activation in patients with COVID-19: A novel therapeutic target. J Allergy Clin Immunol. 2020 Jul;146(1):215-7.

23 Carvelli J, Demaria O, Vély F, Batista L Chouaki Benmansour N, Fares J, et al.; Explore COVID-19 IPH group; Explore COVID-19 Marseille Immunopole group. Association of COVID-19 inflammation with activation of the C5a-C5aR1 axis. Nature. 2020. doi: https://doi.org/10.1038/s41586-020-2600-6.

24 Pengo V, Tripodi A, Reber G, Rand JH, Ortel TL, Galli M, et al.; Subcommittee on Lupus Anticoagulant/Antiphospholipid Antibody of the Scientific and Standardisation Committee of the International Society on Thrombosis and Haemostasis. Update of the guidelines for lupus anticoagulant detection. J Thromb Haemost. 2009 Oct;7(10):1737-40.

25 Garcia D, Erkan D. Diagnosis and Management of the Antiphospholipid Syndrome. N Engl J Med. 2018 May;378(21):2010-21.

26 Lopez LR, Dier KJ, Lopez D, Merrill JT, Fink CA. Anti-beta 2-glycoprotein I and antiphosphatidylserine antibodies are predictors of arterial thrombosis in patients with antiphospholipid syndrome. Am J Clin Pathol. 2004 Jan;121(1):142-9.
Covid-19 with Complement-Mediated Coagulopathy and Severe Thrombosis
Pathobiology 2021;88:28-36 DOI: $10.1159 / 000512503$ 
27 Kelchtermans H, Pelkmans L, de Laat B, Devreese KM. IgG/IgM antiphospholipid antibodies present in the classification criteria for the antiphospholipid syndrome: a critical review of their association with thrombosis. J Thromb Haemost. 2016 Aug;14(8):1530-48.

28 Horstman LL, Jy W, Bidot CJ, Ahn YS, Kelley RE, Zivadinov R, et al. Antiphospholipid antibodies: paradigm in transition. J Neuroinflammation. 2009 Jan;6(1):3-3.

29 Giannakopoulos B, Krilis SA. The pathogenesis of the antiphospholipid syndrome. N Engl J Med. 2013 Mar;368(11):1033-44.

30 Vlachoyiannopoulos PG, Beigbeder G, Dueymes M, Youinou P, Hunt JE, Krilis SA, et al. Antibodies to phosphatidylethanolamine in antiphospholipid syndrome and systemic lupus erythematosus: their correlation with anticardiolipin antibodies and beta 2 glycoprotein-I plasma levels. Autoimmunity. 1993; 16(4):245-9.

31 Wenzel C, Stoiser B, Locker GJ, Laczika K, Quehenberger P, Kapiotis S, et al. Frequent development of lupus anticoagulants in critically ill patients treated under intensive care conditions. Crit Care Med. 2002 Apr;30(4): 763-70.

32 Schouwers SM, Delanghe JR, Devreese KM. Lupus Anticoagulant (LAC) testing in patients with inflammatory status: does $\mathrm{C}$-reactive protein interfere with LAC test results? Thromb Res. 2010 Jan;125(1):102-4.

33 Ortel TL, Erkan D, Kitchens CS. How I treat catastrophic thrombotic syndromes. Blood. 2015 Sep;126(11):1285-93.
34 Sène D, Piette JC, Cacoub P. Antiphospholipid antibodies, antiphospholipid syndrome and infections. Autoimmun Rev. 2008 Feb; 7(4):272-7.

35 Connell NT, Battinelli EM, Connors JM. Coagulopathy of COVID-19 and antiphospholipid antibodies. J Thromb Haemost. 2020. doi: $10.1111 /$ jth. 14893

36 Pierangeli SS, Girardi G, Vega-Ostertag M, Liu X, Espinola RG, Salmon J. Requirement of activation of complement C3 and C5 for antiphospholipid antibody-mediated thrombophilia. Arthritis Rheum. 2005 Jul;52(7):21204.

37 Petri M. Antiphospholipid syndrome. Transl Res. 2020 Nov;225:70-81.

38 Borghi MO, Beltagy A, Garrafa E, Curreli D, Cecchini G, Bodio C, et al. (2020). Prevalence, specificity, and clinical association of antiphospholipid antibodies in COVID-19 patients: are the antibodies really guilty? medRxiv : the Preprint Server for Health Sciences. http://doi.org/https://doi.org/10.1101/202 0.06.17.20134114.

39 Magro CM, Allen J, Pope-Harman A, Waldman WJ, Moh P, Rothrauff S, et al. The role of microvascular injury in the evolution of idiopathic pulmonary fibrosis. Am J Clin Pathol. 2003 Apr;119(4):556-67.

40 Crowson AN, Magro CM, Dawood MR. A causal role for parvovirus B19 infection in adult dermatomyositis and other autoimmune syndromes. J Cutan Pathol. 2000 Nov; 27(10):505-15.

41 Comarmond C, Cacoub P. Granulomatosis with polyangiitis (Wegener): clinical aspects and treatment. Autoimmun Rev. 2014 Nov; 13(11):1121-5.
42 Urban CF, Ermert D, Schmid M, Abu-Abed U, Goosmann C, Nacken W, et al. Neutrophil extracellular traps contain calprotectin, a cytosolic protein complex involved in host defense against Candida albicans. PLoS Pathog. 2009 Oct;5(10):e1000639.

43 Zuo Y, Yalavarthi S, Shi H, Gockman K, Zuo M, Madison JA, et al. Neutrophil extracellular traps in COVID-19. JCI Insight. 2020 Jun; 5(11):138999.

44 de Bont CM, Boelens WC, Pruijn GJ. NETosis, complement, and coagulation: a triangular relationship. Cell Mol Immunol. 2019 Jan; 16(1):19-27.

45 Java A, Apicelli AJ, Liszewski MK, Coler-Reilly A, Atkinson JP, Kim AH, et al. The complement system in COVID-19: friend and foe? JCI Insight. 2020 Aug;5(15):140711.

46 Chee YJ, Ng SJ, Yeoh E. Diabetic ketoacidosis precipitated by Covid-19 in a patient with newly diagnosed diabetes mellitus. Diabetes Res Clin Pract. 2020 Jun;164:108166.

47 Vasil KE, Magro CM. Cutaneous vascular deposition of C5b-9 and its role as a diagnostic adjunct in the setting of diabetes mellitus and porphyria cutanea tarda. J Am Acad Dermatol. 2007 Jan;56(1):96-104.

48 Acosta J, Hettinga J, Flückiger R, Krumrei N, Goldfine A, Angarita L, et al. Molecular basis for a link between complement and the vascular complications of diabetes. Proc Natl Acad Sci USA. 2000 May;97(10):5450-5.

49 Mizuno T, Yoshioka K, Mizuno M, Shimizu M, Nagano F, Okuda T, et al. (2017). Complement component 5 promotes lethal thrombosis. Sci Rep. 2017;7:42714. 